\title{
Effect the single and mixture inoculation with Phosphate solubilizing bacteria, Azotobacter bacteria and P.floresence in growth and production of the corn (Zea mays L.) irrigated with different saline water
}

\author{
Mohamed Saeed Haran and Abdal Zahra Taha Thaher \\ College of Agriculture, University of Basra Iraq \\ Correspondence Author: Mohamed Saeed Haran, College of Agriculture, University of Basra.Iraq \\ E-mail:
}

Received date: 22 January 2019, Accepted date: 14 April 2019, Online date: 25 April 2019

Copyright: (c) 2019 Mohamed Saeed Haran and Abdal Zahra Taha Thaher.2019. This is an open-access article distributed under the terms of the Creative Commons Attribution License, which permits unrestricted use, distribution, and reproduction in any medium, provided the original author and source are credited.

\begin{abstract}
A field experiment was conducted using the Randomized Complete Block Design (RCBD) to evaluate the effect of inoculation with five bacterial inoculants: non-inoculation and inoculation with Phosphate solubilizing bacteria, inoculation with Azotobacter bacteria and inoculation with P.floresence, The mixture bacterial inoculation by interacting with two saline levels of irrigation water $\left(3,6 \mathrm{ds} \cdot \mathrm{m}^{-1}\right)$, adding four levels of phosphorus $(0,40,80,120 \mathrm{~kg} \mathrm{P}$. $\left.\mathrm{ha}^{-1}\right)$ using the superphosphate fertilizer $(52 \% \mathrm{P})$ and nitrogen and potash fertilizers were added to the fertilizing recommendation for yellow corn. The results showed that the mixture inoculation with Phosphate solubilizing bacteria, Azotobacter, and P. fluorescens was excelled on the inoculation treatments of single bacterial in most growth indicators for yellow corn plant which led to reduce the fertilizing recommendation, with a ratio of $33 \%$. The inoculation with Phosphate solubilizing bacteria did not differ significantly from the inoculation with $P$. fluorescence bacteria in the most of studied traits, the mixture bacterial inoculation + salt level $\left(3 \mathrm{ds}^{-\mathrm{m}^{-1}}\right)$ for irrigation water + the levels of phosphorus (120 kg P. ha-1) was excelled in the plant height, dry weight of the total vegetative, total grain yield and leaf area by giving it a percentages $(33.08 \%, 31.90 \%, 61.07 \%, 36.94 \%)$, respectively, compared to the control treatment (non-inoculation, non-fertilization with phosphorus and level of saline water $\left(6 \mathrm{ds}^{-\mathrm{m}^{-1}}\right.$ )).
\end{abstract}

Keywords:

\section{INTRODUCTION}

Biofertilizers of microbial origin can be a good option for sustaining productivity with more environment friendly and integrated nutrient management [2], the fertility and the resultant harvest efficiency because of supplement irregularity in the soil [1], Microorganisms used in Biofertilizers include Phosphate solubilizing bacteria, Mycorrhiza fungus, non and Symbiotic Nitrogen Fixation bacteria, Types of Plant growth-promoting rhizobacteria (PGPR) such as Pseudomonas fluorescens, Trichoderma and others. These bio-fertilizers provide the plant with various nutrient elements such as nitrogen and phosphorus, as well as its production of various types of growth hormones such as Auxins, Gibberellins, and cytokinines, thus reducing the harmful effects of nutrient imbalances in soil resulting from salt stress. Some also can produce antibiotics that effectively contribute to the protection of Plant from pathogens [13]. Phosphorus is considered the second most important mineral nutrient elements after nitrogen; the plant needs it in large quantities. It is one of the determinants of agricultural production for its important role in cell formation, cell division, cellular membrane formation and transmission of genetic traits [16]. However, its availability for the plant depends on the change in soil $\mathrm{pH}$. Where Phosphorus availability reduces in the alkaline media as a result of its deposition with calcium carbonate. Thus, most of the alkaline agricultural land becomes containing large deposits of accumulated phosphorus resulting from the successive annual additives for the phosphate fertilizer [7]. Bio-fertilization was used individually (e.g., inoculation with Phosphate solubilizing bacteria) as a method to improve phosphorus availability in soil [6]; [3]. However, recent studies have suggested that different types of bacteria used in bio-fertilization to inoculate seeds or soil should be mixed at the same time. These organisms encourage plant growth both according to their method [5]; [11]. Yazdani et al. (2009) found that the mixture inoculation for the yellow corn plants with P. putida, p.lentus, A.chrococcum, and A.brasilanse led to an increase in grain yield for the yellow corn from $\left(8.06\right.$ tons.ha $\left.^{-1}\right)$ to $\left(10.27\right.$ tons.ha $\left.^{-1}\right)$ and the biological yield from (15.09 tons.ha $\left.{ }^{-1}\right)$ to (18.26 tons.ha 
${ }^{1}$ ) compared to non-inoculation treatment. Gholami et al., (2008) found that the mixture inoculation for the yellow corn plants with Azotobacter and Azospirillum led to increasing the plant height from $(157.83 \mathrm{~cm})$ to $(175.25 \mathrm{~cm})$ and the dry weight of the total vegetative from (166.49 g.plant $\left.{ }^{-1}\right)$ to $\left(289.58\right.$ g.plant $\left.{ }^{-1}\right)$, increasing the nitrogen content in grain from $\left(2.26 \mathrm{~g} \cdot \mathrm{kg}^{-1}\right)$ to $\left(5.11 \mathrm{~g} \cdot \mathrm{kg}^{-1}\right)$, phosphorus from $\left(0.31 \mathrm{~g} \cdot \mathrm{kg}^{-1}\right)$ to $\left(0.61 \mathrm{~g} \cdot \mathrm{kg}^{-1}\right)$, potassium from $(0.50 \mathrm{~g} \cdot \mathrm{kg}-1)$ to $\left(0.95 \mathrm{~g}_{\mathrm{kg}} \mathrm{kg}^{-1}\right)$, iron from $\left(5.05 \mathrm{~g} . \mathrm{kg}^{-1}\right)$ to $\left(12.38 \mathrm{~g} . \mathrm{kg}^{-}\right.$ $\left.{ }^{1}\right)$, manganese from $\left(0.86 \mathrm{~g} \cdot \mathrm{kg}^{-1}\right)$ to $\left(2.09 \mathrm{~g} \cdot \mathrm{kg}^{-1}\right)$, zinc from $\left(2.73 \mathrm{~g} \cdot \mathrm{kg}^{-1}\right)$ to $\left(5.80 \mathrm{~g} \cdot \mathrm{kg}^{-1}\right)$ and copper from $\left(0.65 \mathrm{~g} \cdot \mathrm{kg}^{-1}\right)$ to $(1.36$ g. $\left.\mathrm{kg}^{-1}\right)$. The mixture inoculation with Plant growth-promoting bacteria led to improving the growth of growing plants under saline stress due to the release of Osmosis resistance materials such as polysaccharides, amino acids, proline, Salicylic acid, ACC deaminase and growth regulators [10]. The aims of this study to determine the effect of single and mixture inoculation with Phosphate solubilizing bacteria, Azotobacter bacteria and P.floresence on the growth and production of yellow corn under salt stress conditions and reduce the amount of phosphate fertilizer added with the recommended fertilization.

\section{MATERIALS AND METHODS}

Phosphate solubilizing bacteria isolates B6 isolated from the Rhizosphere of Alfalfa plant, which showed high efficiency in the dissolving of the insoluble phosphate (Harran and Thaher, 2019 un publisher data). Besides, isolates of P. florescence and isolates of Azotobacter bacteria were obtained from the Department of Plant Protection and the Department of Soil and Water Resources, College of Agriculture, Basra University, respectively. The field experiment was conducted according to the Randomized Complete Block Design (RCBD), with three replicates. The soil of the field that their traits are shown in Table (1) was plowed, the organic material (cows manures) was then added to the soil with the amount of ( 2 tons. ha ${ }^{-1}$ ) for all treatments. The soil is then settled, smoothed and divided into two big plots, each plot is then divided into small plots, with dimensions of $2 \times 3 \mathrm{~m}$ containing the studied experimental treatments and left $1 \mathrm{~m}$ between the trial unit and other. Two furrows were planned in each experimental unit with a length of $3 \mathrm{~m}$ and the distance between the furrow and the other $75 \mathrm{~cm}$. The inoculation of the Phosphate solubilizing bacteria, Azotobacter bacteria and P.floresence were separately prepared. The seeds of the yellow corn were then inoculated through soaking them in the bacterial inoculating for half an hour with the addition of Arabic glue (10\%) to increase the adhesion of the inocula to the seeds. Another group of yellow corn seed is soaked in a non-inoculation solution as a control treatment. After the calibration irrigation with the river water, the seeds of the inoculated and non-inoculated yellow corn were planted in the pit at a depth of approximately $4 \mathrm{~cm}$ and the distance between the pits is $25 \mathrm{~cm}$. Phosphorus was added in the form of triple superphosphate fertilizer $(52 \% \mathrm{P})$ with four levels of $\left(0,40,80,120 \mathrm{~kg} \mathrm{P} . \mathrm{ha}^{-1}\right)$ in one batch at cultivation by feeding method which summarized by placing it in a pit under the line of cultivation at a depth of $10 \mathrm{~cm}$ and then covered with soil. Nitrogen fertilizer was added to urea $46 \% \mathrm{~N}$, with the amount of $\left(280 \mathrm{~kg} \mathrm{~N}\right.$. ha $\left.{ }^{-1}\right)$ in two batches, the first batch was in the stage of vegetative growth and the second before the flowering stage, after 45 days of cultivating. Potassium fertilizer (potassium sulfate) $51 \% \mathrm{~K}$ was added with the amount of $\left(80 \mathrm{~kg} \mathrm{~K} . \mathrm{ha}^{-1}\right)$ in two batches, the first one at cultivating and the second one in the flowering stage.

Table 1: Some chemical, physical and biochemical properties for study soil before cultivating

\begin{tabular}{|c|c|c|}
\hline Traits & Units & Values \\
\hline Electrical conductivity & & 8.92 \\
\hline $\mathrm{pH}$ & & 7.4 \\
\hline Cation exchange capacity & & 14.1 \\
\hline Organic matter $^{\mathrm{CaCO}_{3}}$ & & 4.46 \\
\hline avilable Nitrogen & 36.452 \\
\hline avilable Phosphorus & 21.31 \\
\hline avilable Potassium & 18.46 \\
\hline \multicolumn{2}{|c|}{ Soil particle } & 155.6 \\
\hline Sand & 254.20 \\
\hline Silt & 518.80 \\
\hline Clay & 227.00 \\
\hline Texture & Loam \\
\hline Total number of soil biota CFU (g.soil & -1 & Dry weight) \\
\hline Total bacteria & $4.1 \times 10^{9}$ \\
\hline Total fungi & $0.83 \times 10^{5}$ \\
\hline Azotobacter bacteria & $3.2 \times 10^{4}$ \\
\hline P.floresence bacteria & $1.6 \times 10^{4}$ \\
\hline Phosphate solubilizing bacteria & $0.58 \times 10^{5}$ \\
\hline The values as the average for three replicates
\end{tabular}

* The values as the average for three replicates 
Citation: Mohamed Saeed Haran and Abdal Zahra Taha Thaher, 2019. Effect the single and mixture inoculation with Phosphate solubilizing bacteria, Azotobacter bacteria and P.floresence in growth and production of the corn (Zea mays L.) irrigated with different saline water Advances in Natural and Applied Sciences., 13(1): 22-26. DOI: 10.22587/anas.2019.13.1.4

The crop was irrigated with two levels of salinity of irrigation water $\left(3,6 \mathrm{ds} \cdot \mathrm{m}^{-1}\right)$, after maturation of the crop on 4/7/2018, ten plants were randomly selected from each experimental unit for the treatments to study the field traits of plant height and dry weight of the total vegetative. As for the amount of total yield for the procedure, 5 additional plants were harvested, and their return was quantifiably estimated.

\section{RESULTS AND DISCUSSION}

The results showed that the mixture inoculation, salinity of irrigation water $\left(3 \mathrm{ds} . \mathrm{m}^{-1}\right)$ and the phosphorus level $\left(120 \mathrm{~kg}\right.$ P.ha $\left.{ }^{-1}\right)$ (T4S1P3) led to an increase in plant height with percentage of $33.08 \%$ compared to the non-inoculated, non-fertilization with phosphorus and the saline level of irrigation water is $\left(6 \mathrm{ds} . \mathrm{m}^{-1}\right)$ (T0S2P0). This treatment was not significantly different from (T4S1P2, T4S1P1, T4S2P2, T4S2P3, T3S1P3, T1S1P3, T1S1P2), as shown in Table (2). This indicates that the mixture inoculation with bacteria has reduced the phosphoric fertilizer recommendation by percentage of $33 \%$ and improved plant growth under saline stress conditions due to the susceptibility of the combined inoculation bacteria to increasing the nutrient availability for the plant and excretion it to different growth regulators such as Gibberellins and cytokinins which promote plant growth and elongation it [12].

Table 2: Effect of bacterial inoculation, phosphate fertilizer levels and different irrigation water salinity on plant height (cm) at maturity stage for the corn.

\begin{tabular}{|c|c|c|c|c|c|}
\hline \multirow{2}{*}{ Bio-fertilizer } & \multirow{2}{*}{ Salinity level } & \multicolumn{4}{|c|}{ phosphate fertilizer levels } \\
\hline & & P0 & $\mathrm{P} 1$ & $\mathrm{P} 2$ & P3 \\
\hline \multirow{2}{*}{ Non-inoculation T0 } & S1 & 182.2 & 190.0 & 199.1 & 207.5 \\
\hline & $\mathrm{S} 2$ & 170.8 & 178.6 & 187.8 & 195.6 \\
\hline \multirow{2}{*}{$\begin{array}{l}P S I \\
\text { (T1) }\end{array}$} & S1 & 196.2 & 204.1 & 213.4 & 218.7 \\
\hline & $\mathrm{S} 2$ & 182.6 & 189.2 & 197.4 & 206.8 \\
\hline \multirow{2}{*}{ Azotobacter T2 } & S1 & 185.3 & 192.1 & 201.6 & 208.6 \\
\hline & $\mathrm{S} 2$ & 173.0 & 180.9 & 189.5 & 197.0 \\
\hline \multirow{2}{*}{ P.floresence T3 } & $\mathrm{S} 1$ & 194.6 & 203.7 & 210.9 & 217.6 \\
\hline & $\mathrm{S} 2$ & 185.4 & 193.8 & 202.1 & 209.9 \\
\hline \multirow{2}{*}{$\begin{array}{l}\text { The mixture of } \\
\text { inoculation } \mathrm{T} 4\end{array}$} & S1 & 205.8 & 213.7 & 222.0 & 227.3 \\
\hline & $\mathrm{S} 2$ & 192.9 & 202.5 & 211.8 & 219.2 \\
\hline \multicolumn{2}{|c|}{ LSD 0.05} & \multicolumn{4}{|c|}{16.1746} \\
\hline
\end{tabular}

Also, the treatment of single inoculation with Phosphate solubilizing bacteria (T1S1P3) led to an increase in plant height with percentage of (20.03\%) compared to the non-inoculated and non-fertilization with phosphorus treatment at the level of salinity of irrigation water $\left(3 \mathrm{ds} . \mathrm{m}^{-1}\right)$, which did not differ significantly from the same medication at $\left(80 \mathrm{~kg} \mathrm{P}\right.$. ha $\left.{ }^{-1}\right)$ of phosphate fertilizer (T1S1P2) as shown in Table (2). Table (3) indicates that T4S1P3 gave the highest dry weight for the total vegetative which amounted to $\left(315.9 \mathrm{~g}\right.$. Plant $\left.{ }^{-1}\right)$ with a relative increase of $(31.90 \%)$ compared to the non-inoculated and non-fertilization with phosphorus treatment at the salinity level of irrigation water $\left(6 \mathrm{ds} \cdot \mathrm{m}^{-1}\right)$ (T0S2P0) as shown in Table (3), This is due to the role of bacterial inoculation in increasing the nutrient elements availability for the plants and inducing them to absorb water and increase plant resistance to increase concentration of salt, which is reflected in the dry weight of the plant [14].

Table 3: Effect of bacterial inoculation, phosphate fertilizer levels and different irrigation water salinity on the dry weight for the total vegetative (g.plant ${ }^{-1}$ ) for corn plants at harvest

\begin{tabular}{|c|c|c|c|c|c|}
\hline \multirow{2}{*}{ Bio-fertilizer } & \multirow{2}{*}{ Salinity level } & \multicolumn{4}{|c|}{ phosphate fertilizer levels } \\
\hline & & $\mathrm{P} 0$ & $\mathrm{P} 1$ & $\mathrm{P} 2$ & P3 \\
\hline \multirow{2}{*}{ Non-inoculation T0 } & $\mathrm{S} 1$ & 258.1 & 270.1 & 286.0 & 291.8 \\
\hline & $\mathrm{S} 2$ & 239.5 & 249.8 & 265.3 & 271.0 \\
\hline \multirow{2}{*}{$\begin{array}{c}P S I \\
(\mathrm{~T} 1)\end{array}$} & $\mathrm{S} 1$ & 268.3 & 281.3 & 293.8 & 299.4 \\
\hline & $\mathrm{S} 2$ & 254.2 & 265.2 & 281.1 & 286.7 \\
\hline \multirow{2}{*}{ Azotobacter T2 } & $\mathrm{S} 1$ & 275.7 & 287.9 & 302.2 & 307.8 \\
\hline & $\mathrm{S} 2$ & 263.1 & 276.3 & 288.6 & 294.8 \\
\hline \multirow{2}{*}{ P.floresence T3 } & $\mathrm{S} 1$ & 265.8 & 277.7 & 291.3 & 296.8 \\
\hline & $\mathrm{S} 2$ & 256.6 & 270.6 & 281.1 & 286.5 \\
\hline \multirow{2}{*}{$\begin{array}{l}\text { The mixture of } \\
\text { inoculation } \mathrm{T} 4\end{array}$} & $\mathrm{~S} 1$ & 282.9 & 294.9 & 310.7 & 315.9 \\
\hline & $\mathrm{S} 2$ & 270.0 & 283.4 & 295.3 & 301.7 \\
\hline \multicolumn{2}{|c|}{ LSD 0.05} & \multicolumn{4}{|c|}{12.179} \\
\hline
\end{tabular}


Citation: Mohamed Saeed Haran and Abdal Zahra Taha Thaher, 2019. Effect the single and mixture inoculation with Phosphate solubilizing bacteria, Azotobacter bacteria and P.floresence in growth and production of the corn (Zea mays L.) irrigated with different saline water Advances in Natural and Applied Sciences., 13(1): 22-26. DOI: 10.22587/anas.2019.13.1.4

The same table shows no significant differences between the treatment (T4S1P3) and the treatment (T4S1P2) in the dry weight for the total vegetative, indicating that the mixture inoculation has reduced the phosphoric fertilizer recommendation with the percentage of $(33 \%)$. It is also noted that the single inoculation with the Azotobacter (T2S1P3) led to an increase the dry weight for the total vegetative with percentage $19.5 \%$ compared to the control treatment TOS1P0, which did not differ significantly from the treatment T2S1P2, This is due to the role of Azotobacter bacteria in the fixing of atmospheric nitrogen, which is used to build cells and chlorophyll, thus increase plant growth (9). Table (4) shows that the mixture treatment with bacteria (T4S1P3) gave the highest average for grain yield amounted to (8.084 mag.ha ${ }^{-1}$ ) with a relative increase of $61.07 \%$ compared to the control treatment (non-inoculation) TOS2P0, which recorded the lowest average for grain yield amounted to $\left(5.019 \mathrm{mag}^{-h^{-1}}\right)$. T4S1P3 treatment did not differ significantly from T4S1P2 treatment (7.809 mag.ha $\left.{ }^{-1}\right)$ in its effect on the grain yield for yellow corn. Also, they were not significantly different from the two treatment (T4S2P3, T4S2P2), which amounted their average to $\left(7.350,7.041 \mathrm{mag}^{-1}\right.$ ), respectively. This indicates that the mixture of bacterial inoculation reduces the phosphatic fertilizer recommendation with a percentage of $33 \%$ and improves plant resistance against salt stress conditions. In addition, the single inoculation treatment with Phosphate solubilizing bacteria (T1S1P3) and P. fluorescens (T3S1P3) led to an increase of (31.38\%, 30.49\%), respectively in the yield of grains for the corn, respectively, compared to the non-inoculation, non-fertilization with phosphorus at level of saline water $\left(3 \mathrm{ds} \cdot \mathrm{m}^{-1}\right)$, which did not differ significantly from the treatments (T1S1P2, T3S1P2), indicating the ability of these isolates to provide phosphorus for the plant and reduce the fertilizer recommendation of phosphorus to $33 \%$. This is due to the ability of the common vaccine bacteria to analyze phosphorus-containing metals and to release part of the phosphorus contained within them. These species produce mineral acids that dissolve phosphorus, such as carbonic, nitric and sulfuric acid, as well as many organic acids [15] In addition, the mixture of bacterial inoculation is characterized by its high capacity to provide the plant with nutrient without stopping, on condition, provided that the environmental conditions are suitable for the effectiveness of the bacterial vaccine. Also, the bacterial inoculation enhances the number of bacteria and prevents them from adverse environmental effects such as drought and high temperature during the growth season [4].

Table 4: Effect of bacterial inoculation, phosphate fertilizer levels and different irrigation water salinity on the total yield of grains $\left(\right.$ mag.ha ${ }^{-1}$ ) for corn plants

\begin{tabular}{|c|c|c|c|c|c|}
\hline \multirow{2}{*}{ Bio-fertilizer } & \multirow{2}{*}{ Salinity level } & \multicolumn{4}{|c|}{ phosphate fertilizer levels } \\
\hline & & $\mathrm{P} 0$ & $\mathrm{P} 1$ & $\mathrm{P} 2$ & P3 \\
\hline \multirow{2}{*}{ Non-inoculation T0 } & S1 & 5.746 & 6.158 & 6.562 & 6.910 \\
\hline & $\mathrm{S} 2$ & 5.019 & 5.409 & 5.848 & 6.180 \\
\hline \multirow{2}{*}{$\begin{array}{l}P S I \\
\text { ( T1) }\end{array}$} & S1 & 6.420 & 6.795 & 7.248 & 7.549 \\
\hline & $\mathrm{S} 2$ & 5.779 & 6.157 & 6.610 & 6.942 \\
\hline \multirow{2}{*}{ Azotobacter T2 } & $\mathrm{S} 1$ & 5.820 & 6.206 & 6.660 & 6.998 \\
\hline & $\mathrm{S} 2$ & 5.106 & 5.535 & 5.979 & 6.316 \\
\hline \multirow{2}{*}{ P.floresence T3 } & $\mathrm{S} 1$ & 6.375 & 6.754 & 7.209 & 7.498 \\
\hline & $\mathrm{S} 2$ & 5.963 & 6.342 & 6.799 & 7.076 \\
\hline \multirow{2}{*}{$\begin{array}{l}\text { The mixture of } \\
\text { inoculation } \mathrm{T} 4\end{array}$} & $\mathrm{~S} 1$ & 6.967 & 7.352 & 7.809 & 8.084 \\
\hline & $\mathrm{S} 2$ & 6.283 & 6.682 & 7.041 & 7.350 \\
\hline \multicolumn{2}{|c|}{ LSD 0.05} & \multicolumn{4}{|c|}{1.0558} \\
\hline
\end{tabular}

Table (5) shows that the treatment of the mixture bacterial inoculation and saline level $\left(3 \mathrm{ds} \cdot \mathrm{m}^{-1}\right)$ and the level of $\left(120 \mathrm{~kg} \mathrm{P.} \mathrm{ha}{ }^{-1}\right)$ of phosphate fertilization (T4S1P3) led to an increase in the average of leaf area for the plant amounted to $\left(6309 \mathrm{~cm}^{2}\right)$ and an increase of $36.94 \%$ compared to the control treatment (TOS2P0), which gave the lowest average of leaf area amounted to (4607 $\mathrm{cm}^{2}$ ). The T4S1P3 treatment did not differ significantly from the same treatment at the level of $\left(80 \mathrm{~kg}^{\mathrm{P}}\right.$. ha $\left.{ }^{-1}\right)$ of phosphate fertilizer (T4S1P2). This indicates that the mixture of bacterial inoculation reduced the phosphatic fertilizer recommendation to $33 \%$, This treatment (T4S1P3) did not differ significantly from the single inoculation treatment with Azotobacter and saline level $\left(3 \mathrm{ds}_{\mathrm{m}} \mathrm{m}^{-1}\right)$ and the level of $\left(120 \mathrm{~kg} \mathrm{P} . \mathrm{ha}^{-1}\right)$ of phosphate fertilizer (T2S1P3), This indicates to the efficiency of the Azotobacter bacteria in the fixation of the nitrogen entering the cells and increasing the volume of the total vegetative and the leaf area for the plant. This agrees with [18] indicated that the use of Biofertilizers in the soil led to increasing the efficiency of the plant in the absorbs nutrient elements, enhances cell division, expands leaf cells, and then increases the leaf area of the plant.

Table 5: Effect of bacterial inoculation, phosphate fertilizer levels and different irrigation water salinity on the leaf area $\left(\mathrm{cm}^{2}\right)$ for yellow corn plants

\begin{tabular}{|c|c|c|c|c|c|}
\hline \multirow{2}{*}{ Bio-fertilizer } & \multirow{2}{*}{ Salinity level } & \multicolumn{4}{|c|}{ phosphate fertilizer levels } \\
\cline { 3 - 6 } & & P0 & P1 & P2 & P3 \\
\hline \multirow{2}{*}{ Non-inoculation T0 } & S1 & 5004 & 5224 & 5512 & 5628 \\
\cline { 2 - 6 } & S2 & 4607 & 4856 & 5140 & 5269 \\
\hline PSI & S1 & 5375 & 5594 & 5863 & 5968 \\
\hline
\end{tabular}


Citation: Mohamed Saeed Haran and Abdal Zahra Taha Thaher, 2019. Effect the single and mixture inoculation with Phosphate solubilizing bacteria, Azotobacter bacteria and P.floresence in growth and production of the corn (Zea mays L.) irrigated with different saline water Advances in Natural and Applied Sciences., 13(1): 22-26. DOI: $10.22587 /$ anas.2019.13.1.4

\begin{tabular}{|c|c|c|c|c|c|}
\hline ( T1) & S2 & 5024 & 5236 & 5499 & 5617 \\
\hline \multirow{2}{*}{ Azotobacter T2 } & S1 & 5503 & 5709 & 6074 & 6226 \\
\cline { 2 - 6 } & S2 & 5255 & 5466 & 5752 & 5839 \\
\hline \multirow{2}{*}{ P.floresence T3 } & S1 & 5310 & 5527 & 5774 & 5953 \\
\cline { 2 - 6 } & S2 & 5189 & 5390 & 5678 & 5779 \\
\hline \multirow{2}{*}{ The mixture of inoculation T4 } & S1 & 5736 & 5982 & 6221 & 6309 \\
\cline { 2 - 6 } & S2 & 5370 & 5570 & 5842 & 5946 \\
\hline \multicolumn{5}{|c|}{234.133} \\
\hline
\end{tabular}

\section{REFERENCES}

[1] AL-Taey, D. K. A., S. S. M. AL-Azawi, M. J. H. AL-Shareefi, and A. R. AL-Tawaha (2018) Effect of saline water, NPK and organic fertilizers on soil properties and growth, antioxidant enzymes in leaves and yield of lettuce (Lactuca sativa var. Parris Island) Res. Crops $19: 441-449$.

[2] Al-Taey, D. K. A., Z. Z. Majid. THE ACTIVITY OF ANTIOXIDANTS ENZYMES AND NPK CONTENTS AS AFFECTED BY WATER QAULITY, KINETIN, BIO AND ORGANIC FERTILIZATION IN LETTUCE (Lactuca sativa L.). Iraqi Journal of Agricultural Sciences: 49(3):506- 518, 2018.

[3] Abd El-Ghany,Bouthaina.F.;A.M.Arafa,Rawhia..;Tomader, El-Rahmany. And, Mona.Morsy.El-Shazly.(2010). Effect,of,some,soil Microorganisms on soil properties and Wheat production under north, Sinai, conditions .Journal,, Applied Sciences Research,4(5):559-579.

[4] Abd El-GhanyT.M., M.M. Alawlaqi and M.A. Al Abboud. (2013). Role of biofertilizers in agriculture: a brief review . Mycopath (2013) 11(2): 95-101.

[5] Al-Shamma, Utoor Hussam Al-Deen. (2013). Integration effect of nitrogen fixing bacteria isolated from soil and sub recommended rates of chemical fertilizers on growth and yield of wheat Triticum aestivum L. Msc. Thesis,College of Science Univ.of Baghdad..

[6] El-Komy, H. M. (2005). Coimmobilization of Azospirillum lipoferm and Bacillus megaterium for successful phosphorus and Nitrogen nutrition of wheat plants. J. Food. Technol. Biotechnol. Vol. 43(1): 19-27.

[7] FNCA, .(2006) . forum for Nuclear Cooperation in Asia,Biofertilizer mamuad.

[8] Gholami, A. ; A. Biari, and Nezarat . (2008). Effect of seed priming with growth promoting Rhizobacteria at different Rhizosphere condition on growth parameter of Maize. International Meeting on Soil Fertility Land Management and Agroclimatology. Turkey.

[9] Havlin, J.L.; J. D. Beaton ; S .L. Tisdale and W.L. Nelson. (2005). Soil Fertility \& Fertilizers" An Introduction to Nutrient Management"7th Ed. Prentice Hall . New Jersey.

[10] Khan,K.S.and R.G.Joergensen. (2009). chang-es in microbial biomass and P.fractions in bio-genic household waste compost amended with inorganic P.fertilizers.Bioresour.Technol.100: 303-309.

[11] Moinuddin , Tariq Ahmad Dar, Sajad Hussain, M. Masroor Akhtar Khan , Nadeem Hashmi , Mohammad Idrees , Mohammad Naeem and Akbar Ali. (2014). Use of N and P biofertilizers together with phosphorus fertilizer Improves growth and physiological attributes of chickpea. Vol. 2 (3), pp. 168-174, October, 2014. Global Science Research Journals.

[12] Schoebitz, M., Simonin, H., Poncelet, D. (2012). Starch filler and osmoprotectants improve the survival of rhizobacteria in dried alginate beads. J. Microencapsul. 29, 532-538.

[13] Siddikee, M. A., P. S. Chauhan, R. Anandham, Gwang-Hyun Han, and Tongmin Sa. (2011). Isolation, Characterization, and Use for Plant Growth Promotion Under Salt Stress, of ACC Deaminase-Producing Halotolerant Bacteria Derived from Coastal Soil. J. Microbiol. Biotechnol. 1577-1584.

[14] Sofiana R, Reginawanti H.and Betty N. Fitriatin.(2017). Role of Azotobacter sp. On Nitrogen Uptake and Growth of Soybean (Glycine max (L.)Merrill) on Saline Soil. International Journal of Scientific \& Engineering Research.ISSN 2229-5518.

[15] Wu, Z., Guo, L., Qin, S., Li, C. (2012). Encapsulation of R. planticola Rs-2 from alginate-starch-bentonite and its controlled release and swelling behavior under simulated soil conditions. J. Ind. Microbiol. Biotechnol. 39, 317-27.

[16] Xiao CQ, Chi RA, He H, Qiu GZ, Wang DZ, Zhang WX (2011). Isolation of phosphate solubilizing fungi from phosphate mines and their effect on wheat seedling growth. Appl. Biochem. Biotechnol. 159:330-342.

[17] Yazdani, M.; M. K. Bahmanyar; H. Pirdashti; M.A. Esmaile. (2009). Effect of phosphate solubilization microorganism (PSM) and plant growth promotion rhizobacteria (PGPR) on yield componenets of corn (Zea mays L.) : World Academy of Science,Engineering and Technology . $37:$ 90-92.

[18]Zafar,M,M.K.Abbasi,A,Khaliq and Z.ur-Rehman. (2011). Effect of Combining materials with inorganic phosphorus sources on growth, yield, energy content and phosphorus uptake in maize at Rawalakot Azad Jammu and Kashmir, Pakistan. Applied Science Research,3(2):199-212. 